\title{
Strengthened Ebola surveillance in France during a major outbreak in West Africa: March 2014-January 2016
}

\author{
A. MAILLES ${ }^{1}$, H. NOEL ${ }^{1}$, D. PANNETIER ${ }^{2}$, C. RAPP ${ }^{3}$, \\ Y. YAZDANPANAH ${ }^{4}$, S. VANDENTORREN ${ }^{1}$, P. CHAUD ${ }^{1}$ \\ J. M. PHILIPPE ${ }^{5}$, B. WORMS ${ }^{5}$, M. BRUYAND ${ }^{1}$, M. TOURDJMAN ${ }^{1}$, \\ M. NAHON ${ }^{6}$, E. BELCHIOR ${ }^{1}$, E. LUCAS ${ }^{1}$, J. DURAND ${ }^{1}$, \\ M. ZURBARAN ${ }^{1}$, S. VAUX ${ }^{1}$, B. COIGNARD ${ }^{1}$, H. DE VALK ${ }^{1}$, \\ S. BAIZE ${ }^{2}$, S. QUELET ${ }^{1}$, F. BOURDILLON ${ }^{1}$, on Behalf of \\ the French EVD Team $\dagger$ \\ ${ }^{1}$ French National Public Health Agency, Saint-Maurice, France \\ ${ }^{2}$ French Reference Center for Viral Hemorrhagic Fevers, Lyon, France \\ ${ }^{3}$ Hopital d'Instruction des Armées Begin, Saint-Mandé, France \\ ${ }^{4}$ Hôpital Universitaire Bichat, Paris, France \\ ${ }_{6}^{5}$ Ministry of Health, Paris, France \\ ${ }^{6}$ Samu de Paris, Paris, France
}

Received 2 May 2017; Final revision 14 September 2017; Accepted 25 October 2017; first published online 23 November 2017

\begin{abstract}
* Author for correspondence: A. Mailles, Santé Publique France, Infectious Diseases Department, 12 rue du Val d'Osne, 94415 Saint Maurice cedex, France.

(Email: alexandra.mailles@santepubliquefrance.fr)

\section{$\dagger$ The French EVD Team members are:}

Florence Ader (University hospital, Lyon, France), Delphine Antoine (French national Public Health Agency, Saint-Maurice, France), Philippe Bourrier (Ministry of Health, Paris, France), Philippe Brouqui (University hospital, Marseille, France), François Caron (University Hospital, Rouen, France), Jean-Loup Chappert (French national Public Health Agency, Lyon, France), Didier Che (French national Public Health Agency, Saint-Maurice, France), Christian Chidiac (University hospital of Lyon, France), Hélène Coignard-Biehler (SAMU de Paris and University Hospital Necker, Paris, France), Manuel Etienne (University Hospital, Rouen, France), Karine Faure (University hospital of Lille), Tristan Ferry (University hospital of Lyon, France), France), Laurent Filleul (French national Public Health Agency, Saint-Denis, France), Clara Flateau (HIA Begin, Saint-Mandé, France), Franck Golliot (French national Public Health Agency, Montpellier, France), François Goehringer (University hospital, Nancy, France), Benoit Guery (University hospital of Lille, France), Bruno Grandbastien (University hospital of Lille, France), Yves Hansmann (University hospital of Strasbourg, France), Magid Herida (French national Public Health Agency, Saint-Maurice, France), Dominique Jeannel (French national Public Health Agency, Orléans, France), Lisa King (French national Public Health Agency, Rennes, France), Marie Lachâtre (University Hospital Bichat, Paris, France), Martine Ledrans (French national Public Health Agency, Fort-France, France), Philippe Malfait (French national Public Health Agency, Marseille, France), Denis Malvy (University hospital, Bordeaux, France), Jean-Claude Manuguerra (Institut Pasteur, Paris, France), Sophie Matheron (University Hospital Bichat, Paris, France), Thierry May (University Hospital, Nancy, France), Audrey Merens (HIA Begin, Saint-Mandé, France), Patrick Miailhes (University hospital of Lyon, France), Christian Michelet (University hospital, Rennes), Marie-Pierre Moiton (University hospital, Saint-Denis de la Réunion, France), Damien Mouly (French national Public Health Agency, Toulouse, France), Delphine NGuyen (Ministry of Health, Paris, France), Jerome Naud (French national Public Health Agency, Saint-Maurice, France), Ronan Ollivier (French national Public Health Agency, Nantes, France), Thomas Perpoint (University hospital of Lyon, France), Jerome Pozuelos (French national Public Health Agency), Christian Rabaud (University Hospital, Nancy, France), Mathieu Revest (University hospital, Rennes), Christophe Rioux (University Hospital Bichat, Paris, France), France Roblot (University hospital of Poitiers, France), Véronique Servas (French national Public Health Agency, Bordeaux, France), Guillaume Spaccaferri (French national Public Health Agency, Clermont-Ferrand, France), Jean-Paul Stahl (University hospital, Grenoble, France), Pierre Tattevin (University hospital, Rennes, France), Claude Tillier (French national Public Health Agency, Dijon, France), Renaud Verdon (University hospital of Caen, France), Jenifer Yai (French national Public Health Agency, Nancy, France).
\end{abstract}




\section{SUMMARY}

\section{Introduction}

An unprecedented outbreak of Ebola virus diseases (EVD) occurred in West Africa from March 2014 to January 2016. The French Institute for Public Health implemented strengthened surveillance to early identify any imported case and avoid secondary cases.

\section{Methods}

Febrile travellers returning from an affected country had to report to the national emergency healthcare hotline. Patients reporting at-risk exposures and fever during the 21st following day from the last at-risk exposure were defined as possible cases, hospitalised in isolation and tested by realtime polymerase chain reaction. Asymptomatic travellers reporting at-risk exposures were considered as contact and included in a follow-up protocol until the 21 st day after the last at-risk exposure.

\section{Results}

From March 2014 to January 2016, 1087 patients were notified: 1053 were immediately excluded because they did not match the notification criteria or did not have at-risk exposures; 34 possible cases were tested and excluded following a reliable negative result. Two confirmed cases diagnosed in West Africa were evacuated to France under stringent isolation conditions. Patients returning from Guinea $(n=531 ; 49 \%)$ and Mali $(n=113 ; 10 \%)$ accounted for the highest number of notifications.

\section{Conclusion}

No imported case of EVD was detected in France. We are confident that our surveillance system was able to classify patients properly during the outbreak period.

Key words: Ebola, France, outbreak, surveillance.

\section{INTRODUCTION}

Ebola virus was first identified in 1976 during two simultaneous outbreaks in Sudan and the Democratic Republic of Congo (DRC) [1, 2]. The main ways of transmission of the virus were identified early during these outbreaks and include direct contacts with patients or their bodily fluids, especially during healthcare and funerals settings. Although the ecology of Ebola virus is not completely understood, outbreaks in humans frequently start following human interaction with infected wild animals such as during hunting, or skinning activities or preparation of bush meat from various infected animals (bats, monkeys, antelopes).

In March 2014, the National Reference Center (NRC) for viral haemorrhagic fevers (FHV) in Lyon confirmed Zaire Ebola virus as the causative agent of an outbreak of illness that was ongoing in Guinea since December 2013 [3]. The outbreak rapidly spread to the neighbouring Liberia and Sierra Leone with unprecedented numbers of cases. WHO declared the outbreak a public health emergency of international concern in August 2014. Nigeria, Mali and Senegal recorded Ebola virus disease (EVD) cases directly related to this outbreak but the viral transmission was promptly controlled in these countries. On 15 January 2016, WHO declared the end of the outbreak in West Africa, with a total of 28610 cases (15221 confirmed, 2622 probable and 10767 suspected) reported including 11610 deaths (Fig. 1) [4].

The outbreak in West Africa was considered a major threat because it took place in urban areas as well as rural, because the number of cases and geographical extend of the outbreak were greater than during any other EVD outbreaks, and because people in West Africa, including infected persons, were able to travel fast over hundreds of kilometres during their incubation period, and sometimes internationally.

In 2014, a virologically distinct outbreak occurred from 24 August to 16 November 2014 in the province of Equateur in DRC. Seventy-eight cases were identified, with 49 deaths.

In France, EVD is a mandatory notifiable disease since 1986. Three of the countries affected by the 2014/2016 EVD outbreak, Guinea, Mali and DRC, are highly connected with France, with respectively 67045,157023 and 69254 passengers flying to or from these countries in 2014 [5]. Their administrative language is French. An average of 2000 French citizens live in Guinea, 2500 in DRC and 7000 in Mali. Moreover an estimated 9000 citizens from Guinea, 

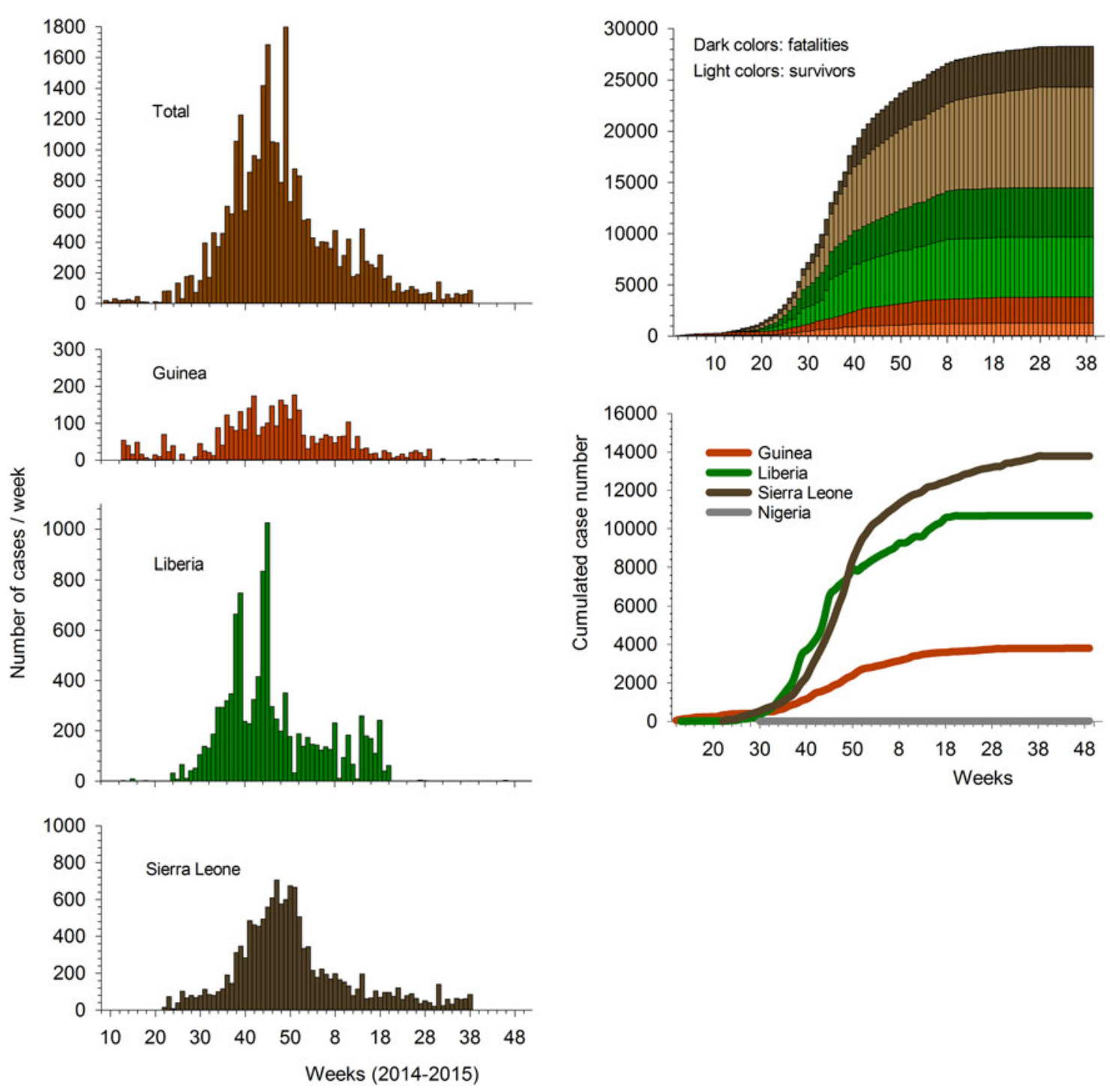

Fig. 1. Number of probable and confirmed cases notified to the WHO, by date and country of notification, West Africa 2014-2016.

34000 citizens from DRC and 41000 citizens from Mali live in France [6]. It was therefore feared that patients infected by Ebola virus could travel to France, and trigger further transmission. A model estimated that one EVD case would be imported in France from these countries every 10 months [7]. It was therefore decided to strengthen the surveillance system in France during this outbreak.

The main objective of the strengthened surveillance was to early identify any imported case, and to avoid secondary transmission whether in the community or among healthcare workers (HCW). The second objective was to quickly rule out EVD diagnosis in patients presenting with symptoms suggestive of EVD to allow appropriate clinical management in the usual infection control security conditions.

\section{METHODS}

\section{Case definitions}

A suspected case of EVD was a traveller returning from an affected area within the last 21 days, and presenting with fever $\geqslant 38^{\circ} \mathrm{C}$. An affected area was defined as any country with documented Ebola virus transmission up to 42 days after the last documented case, according to the WHO criteria.

A possible case was a suspected case who reported an at-risk exposure (see below) during the 21 days before the onset of symptoms, or whose at-risk exposures could not be evaluated (if the patient was unconscious, e.g.).

A confirmed case was defined as a person with a positive biological diagnosis obtained by real-time polymerase chain reaction (RT-PCR) in an authorised 
laboratory, and confirmed by the NRC for FHV, or obtained by serology or RT-PCR in the NRC.

A case was excluded if the criteria for suspected case or possible case were not fulfilled, or if the biological diagnostic tests, carried out in an authorised laboratory under the supervision of the NRC were negative.

\section{Early management and notification of patients}

Persons returning from the outbreak area were advised to call the national emergency hotline (Samu-centre 15) for EVD risk assessment in the event of any symptom. They were discouraged to seek medical attention directly by their general practitioners or in a hospital. The persons who called Samu-centre 15 in this context had to be notified immediately to Santé Publique France, the French National Public Health Agency (formerly known as Institut de veille sanitaire) to verify if they matched the case definition criteria for suspected case and for the assessment of their at-risk exposures (see below). If a person matching the case definition for suspected case decided to seek medical attention directly in a hospital or by their family doctor, then they were notified to SAMU-centre 15 by the hospital or the family doctor before any medical examination.

\section{Assessment of at-risk exposures}

At-risk exposures were investigated in notified patients before any medical examination by the clinician of the Samu-centre 15, and by an epidemiologist of Santé Publique France, using a standardised questionnaire. More specifically, at-risk exposures were defined as:

- Direct contact with EVD patients, either biologically confirmed or not, or with their bodily fluids, either in a medical facility or a community settings;

- Having actively participated in funerals (washing or carrying the body of the deceased);

- Having undergone invasive medical procedures in a hospital that recently cared for EVD patients;

- Working in a laboratory that holds Ebola virus or biological samples from Ebola patients;

- Direct contact with animals known to be possible reservoirs of the virus (monkeys, bats, antelopes);

- Hunting in the affected area or having manipulated/ prepared bush meat;

- Having been cared for by a traditional healer in an affected area;

- Sexual intercourse with an EVD patient, even after his/her recovery.
For non-French-speaking persons, a translation service was made available.

If an at-risk exposure could not be ruled out (unreliable interview, or patients unable to answer), or in case of classification of a possible case, a conference call was immediately held with the attending physician, the virologist of the NRC, an epidemiologist of Santé publique France and the infectious diseases specialist of the referral hospital to assess the risk of EVD and decide about the patient's classification and further clinical management.

Possible cases had to be hospitalised and cared for in one of the 15 French referral hospitals designated by the Ministry of Health for the management of EVD patients [8]. EVD confirmed cases diagnosed abroad in the affected area could be evacuated to France to be managed and taken care of, with the authorisation of the French Ministry of Health.

\section{Viral diagnosis}

Possible cases were tested for EVD by RT-PCR. At the NRC, possible cases were tested using a generic filovirus RT-PCR, as well as a specific Ebola Zaire RT-PCR. According to their history and at-risk exposures, the possible cases were also tested for other BSL4 pathogens, such as Marburg, Lassa or Crimean-Congo haemorrhagic fever viruses. Confirmed cases were followed-up by the daily assessment of their viral load in various samples.

Seven out of the 15 referral hospitals and the Laboratory for Urgent Response to Biological Threats (CIBU, Institut Pasteur) had the capacity to specifically test for Ebola Zaire virus using the Altona Ebola RT-PCR [9]. Results had to be verified by the NRC.

Possible cases with a negative RT-PCR on an early sample (within 2 days after the onset of fever), had to be tested again by PCR on a sample taken more than 2 days after the onset, or could be excluded by collegial decision when their medical condition was spontaneously improving after the first negative test.

Possible cases tested more than 10 days after the onset of symptoms, or who were recovering at the time of the diagnosis were also tested by serology. In that case, ELISA allowing detecting EBOV-specific IgM and IgG were used in addition to EBOV-specific RT-PCR. On the contrary to RT-PCR, in-house ELISA was only performed by the NRC. 

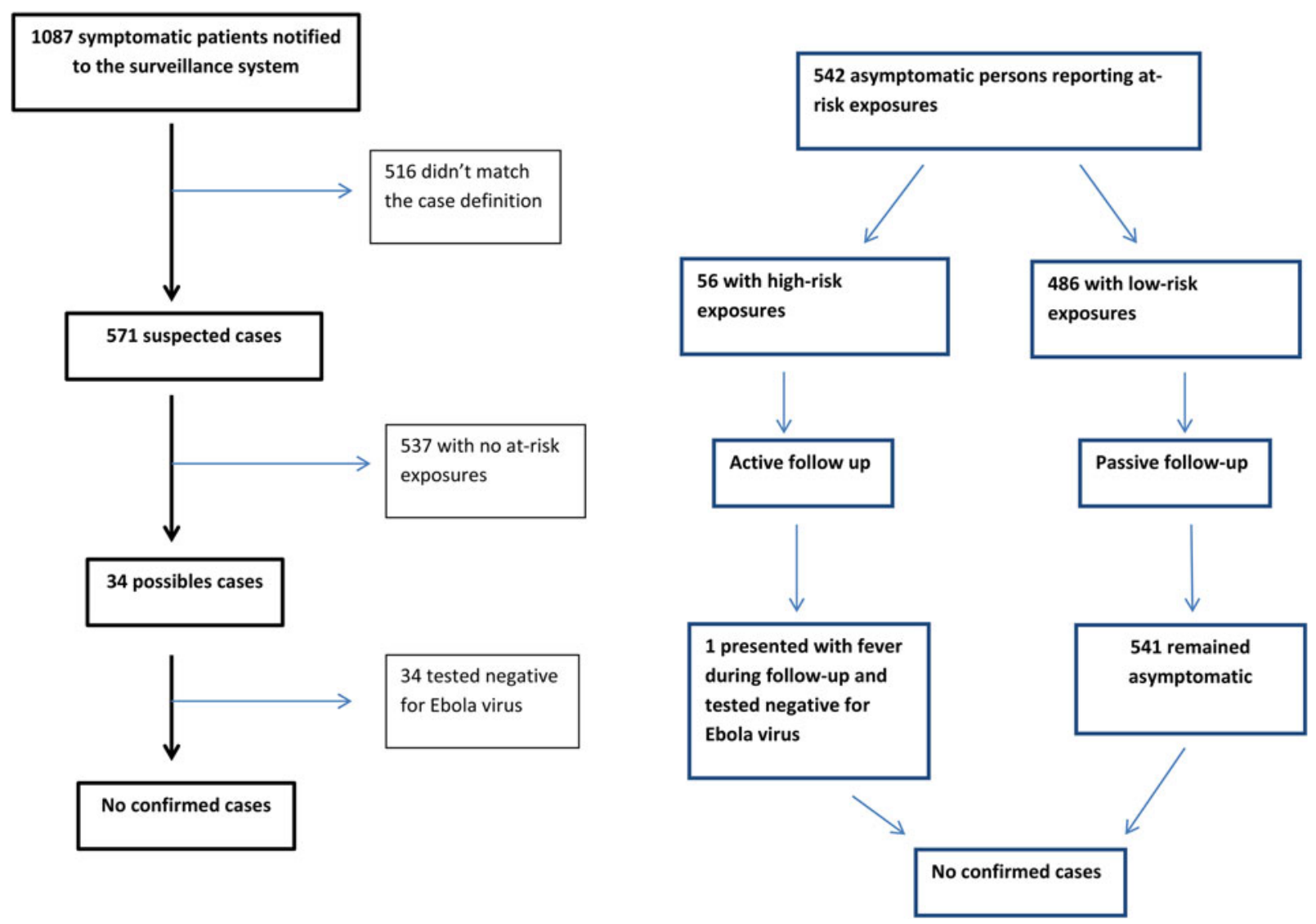

Fig. 2. Flow diagram of notifications of cases and contact persons.

\section{Follow-up of contact persons}

Contact persons were defined as

- Persons reporting at-risk exposures in the last 21 days in the absence of fever;

- Potentially exposed French HCW

Contact persons with high-level risk according to the European Centre for Disease Prevention and Control (ECDC) criteria were followed up actively [10]. They were advised to measure their body temperature twice daily, and were called every day during 21 days after their return by a healthcare professional from the regional health agency to check on the absence of fever or other symptoms. Contact persons with low-level risk were advised to self-monitor their body temperature during 21 days and they were given a phone number to call immediately in case of fever or other symptoms.

\section{Data management}

Data were computerised using a secure, web-based application Voozanoo(C (Epiconcept, Paris). For the purpose of investigation and follow-up, nominative data were recorded. The presented work was carried out with the approval of the French Commission for data Protection ('Commission Nationale Informatique et Liberté'). Nominative data were deleted 1 month after the date of classification or the end of the follow-up period.

Data were analysed using Stata 12C (Stata corporation, College Station, Texas, USA).

\section{RESULTS}

\section{Characteristics of notified patients}

From 23 March 2014 to 15 January 2016, 1087 patients were notified to the strengthened surveillance system (Fig. 2). The male/female sex ratio of notified patients was $1 \cdot 5$. Their median age was 30 years old (min: <1 year old, max: 95 years old), and $21 \%$ were children under 16 years old.

Of 1087 notified patients, $516(47 \%)$ did not match one or more criteria for suspected or possible case and were immediately excluded: 


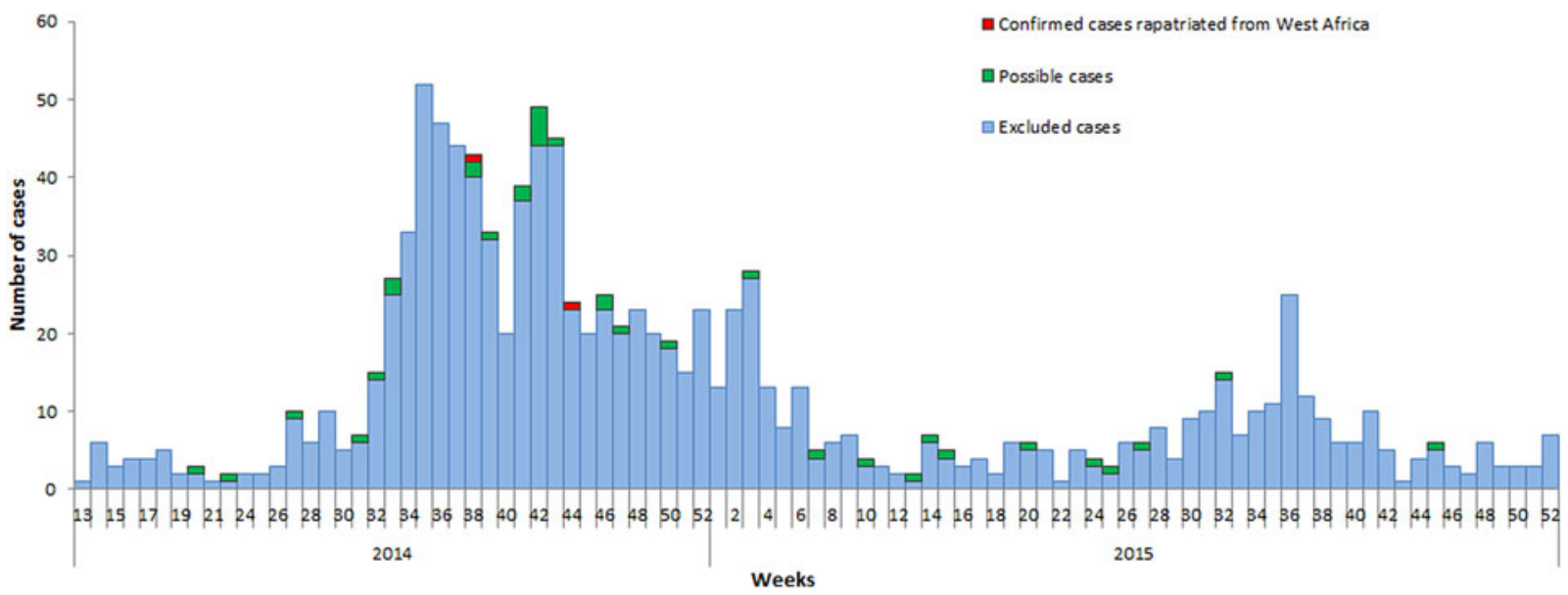

Fig. 3. Distribution of notified patients by date of notifications and final status of cases, surveillance of EVD, France 2014-2016.

- 292 never displayed fever;

- 281 had not visited an at-risk country;

- 52 presented with fever more than 21 days after returning from the affected area.

Finally, $571(53 \%)$ patients met the criteria for suspected cases. Thirty-four (3\%) patients were classified as possible cases, hospitalised in isolation and tested for EVD: all 34 were finally excluded following negative PCR or serology results.

In addition to the 1087 patients notified to the strengthened surveillance system, two confirmed cases were medically evacuated to France from an affected country and are also included in our study.

The trend in notifications in France followed closely the epicurve of the African outbreaks (Figs 1 and 3). Two additional peaks in notifications were observed: one at the end of the summer holidays 2014, due to an increased number of travellers returning from the affected area. The second peak occurred in October 2014, a few days after healthcare-related transmissions were reported in Spain [11] and Texas [12].

A median of six notifications were received weekly (min: one, max: 52), of which 269 (25\%) during weekends. The district of residence or stay of the patients at the time of the notification was known for 1018 patients: $442(44 \%)$ lived or stayed in Ile-de-France region ( = Paris and surroundings) (Fig. 4).

Among 1089 included patients, 808 (74\%) had travelled in one or more country affected by the outbreak (at-risk periods according to the WHO) (Table 1). Data about visited country were missing for five notified patients.

Notified patients were interviewed about their possible at-risk exposures:
- $49(4 \cdot 5 \%)$ were HCW, of whom 32 physicians and nurses, four laboratory workers, one hospital hygienist and four working in administrative or support functions. Occupation was not known for eight patients;

- $22(0 \cdot 2 \%)$ had been hospitalised in a hospital or a clinic managing EVD patients before the implementation of Ebola treatment centres, or in an hospital/ clinic where Ebola patients were discovered despite the triage;

- $17(0.02 \%)$ visited a relative or friend in a hospital or a clinic where EVD patients were also hospitalised;

- $15(1 \cdot 3 \%)$ patients participated in funerals, one of them reporting carrying the body of the deceased person to the graves and two reported participating in the burials. None reported cleaning the body of the deceased person;

- $8(0 \cdot 7 \%)$ notified patients reported direct contact with EVD patients in non-medical settings;

- $7(0.6 \%)$ reported handling raw bush meat for meal preparation (namely antelope meat for six and frog meat for one);

- $4(0 \cdot 4 \%)$ patients had sought medical attention from a traditional healer in an affected area;

$-2(0 \cdot 2 \%)$ reported direct contact with wild animals (one with bat and one with an unidentified rodent);

- $1(0 \cdot 1 \%)$ reported sexual intercourse with a patient who had recovered from EVD.

\section{Possible cases}

Thirty-four patients ( $3 \%$ of all notifications and $6 \%$ of patients matching the suspected case definition) were considered possible cases (Table 2). Among those 


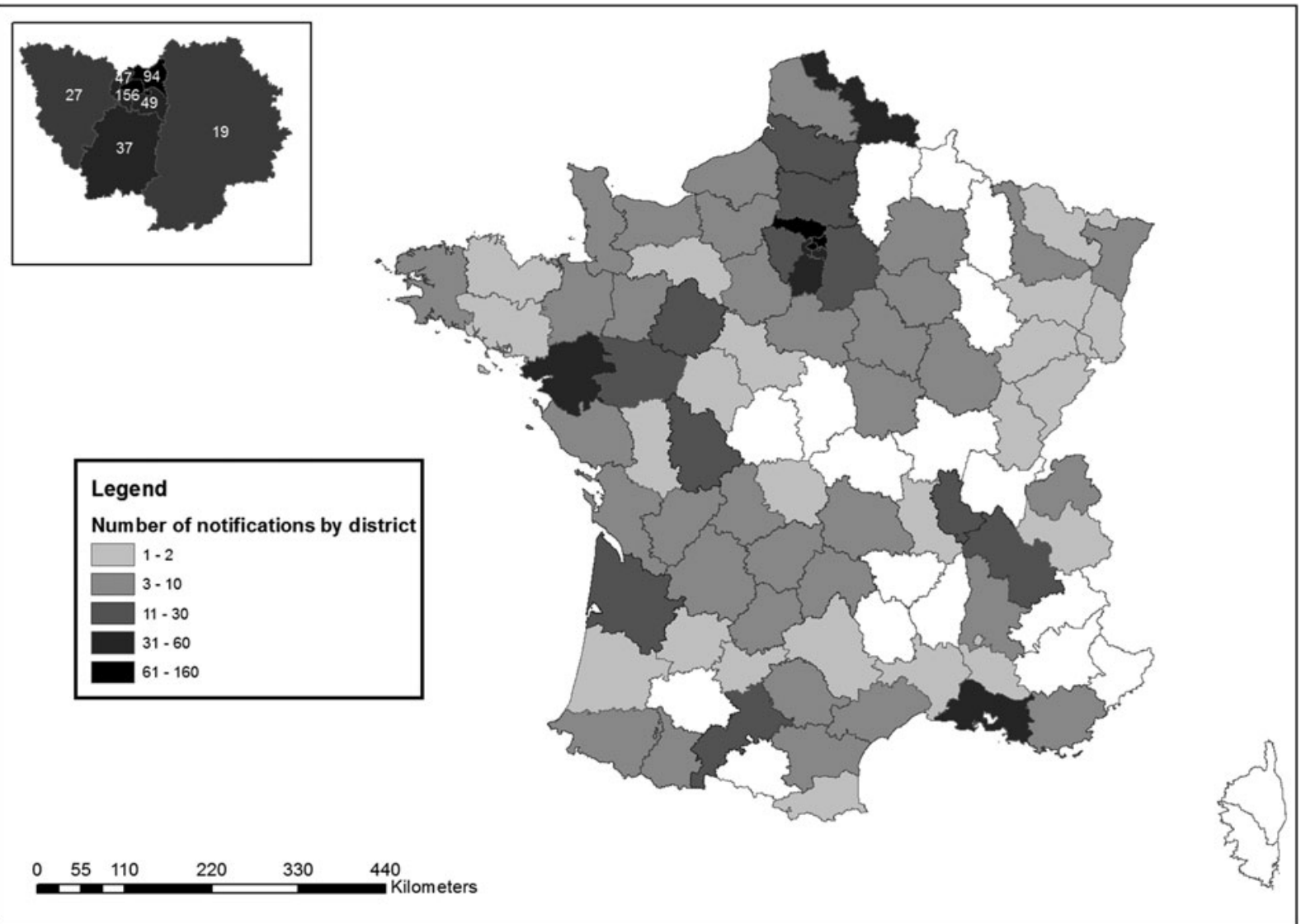

Fig. 4. Distribution of cases by district of notification, surveillance of EVD, France 2014-2016.

Table 1. Number of notified patients by affected country, surveillance of EVD, France 2014-2016

\begin{tabular}{|c|c|c|c|c|}
\hline $\begin{array}{l}\text { At-risk } \\
\text { country }\end{array}$ & $\begin{array}{l}\text { Number of notifications } \\
\text { in returning travellers }\end{array}$ & $\begin{array}{l}\% \text { of notifications received } \\
\text { during the complete } \\
\text { outbreak period }\end{array}$ & $\begin{array}{l}\text { Specific outbreak period } \\
\text { in the country, as } \\
\text { defined by WHO }\end{array}$ & $\begin{array}{l}\% \text { of notification received } \\
\text { during the country-specific } \\
\text { outbreak period }\end{array}$ \\
\hline Guinea & 531 & 49 & $\begin{array}{l}23 \text { March 2014-15 } \\
\text { January } 2016\end{array}$ & 49 \\
\hline Sierra Leone & 33 & 3 & $\begin{array}{c}23 \text { March 2014-9 } \\
\text { November } 2015\end{array}$ & 3 \\
\hline Liberia & 21 & 2 & $\begin{array}{l}\text { First episode: } 23 \text { March } \\
\text { 2014-9 May } 2015 \\
\text { Second episode: } 1 \text { July } \\
\text { 2015-3 September } \\
2015\end{array}$ & First: $2 \cdot 3$; second: 0 \\
\hline Nigeria & 57 & 5 & $\begin{array}{l}8 \text { August } 2014-20 \\
\text { October } 2014\end{array}$ & 36 \\
\hline Mali & 113 & 10 & $\begin{array}{l}14 \text { November 2014-18 } \\
\text { January } 2015\end{array}$ & 55 \\
\hline $\mathrm{DRC}$ & 71 & 7 & $\begin{array}{l}25 \text { August 2014-24 } \\
\text { November } 2014\end{array}$ & 45 \\
\hline
\end{tabular}

The total of travellers exceeds 808 because some travellers visited several countries. 
Table 2. Description of possible cases, surveillance of EVD, France 2014-2016

\begin{tabular}{|c|c|c|c|}
\hline Sex, age & $\begin{array}{l}\text { Visited } \\
\text { country }\end{array}$ & $\mathrm{HCW}$ & Clinical presentation \\
\hline Male, 20s & Guinea & No & $\begin{array}{l}\text { Arthralgia, myalgia, sore throat, swallowing } \\
\text { difficulties, history of fever }\end{array}$ \\
\hline Male, 30s & Guinea & Yes & High grade fever \\
\hline $\begin{array}{l}\text { Female, } \\
40 \mathrm{~s}\end{array}$ & Guinea & No & Fever $\left(38.5^{\circ} \mathrm{C}\right)$, rash \\
\hline $\begin{array}{l}\text { Female, } \\
40 \mathrm{~s}\end{array}$ & Guinea & No & $\begin{array}{l}\text { Fever }\left(39^{\circ} \mathrm{C}\right) \text {, diarrhoea, vomiting, } \\
\text { asthenia, anorexia }\end{array}$ \\
\hline $\begin{array}{l}\text { Teen-aged } \\
\text { female }\end{array}$ & Guinea & No & High grade fever $\left(40^{\circ} \mathrm{C}\right)$, pharyngitis \\
\hline $\begin{array}{l}\text { Male, } \\
\text { nineties }\end{array}$ & Guinea & No & $\begin{array}{l}\text { History of fever, fainting episode, } \\
\text { dehydration, diarrhoea }\end{array}$ \\
\hline $\begin{array}{l}\text { Teen-aged } \\
\text { male }\end{array}$ & Guinea & No & $\begin{array}{l}\text { History of fever, diarrhoea, cough, } \\
\text { abdominal pain }\end{array}$ \\
\hline Male, 40s & Guinea & No & History of fever, diarrhoea \\
\hline Male, 30s & Guinea & No & $\begin{array}{l}\text { Fever }\left(39 \cdot 7^{\circ} \mathrm{C}\right) \text {, diarrhoea, headaches, } \\
\text { myalgia }\end{array}$ \\
\hline $\begin{array}{l}\text { Female, } \\
30 \mathrm{~s}\end{array}$ & Guinea & Yes & $\begin{array}{l}\text { History of fever, diarrhoea, headache, sore } \\
\text { throat }\end{array}$ \\
\hline $\begin{array}{l}\text { Female, } \\
\text { 30s }\end{array}$ & Liberia & No & $\begin{array}{l}\text { History of fever, cough, myalgia, arthralgia, } \\
\text { headaches, diarrhoea }\end{array}$ \\
\hline $\begin{array}{l}\text { Female, } \\
40 \mathrm{~s}\end{array}$ & Guinea & No & $\begin{array}{l}\text { History of fever, asthenia, diarrhoea, } \\
\text { abdominal pain }\end{array}$ \\
\hline $\begin{array}{l}\text { Female, } \\
30 \mathrm{~s}\end{array}$ & Guinea & No & $\begin{array}{l}\text { History of fever, disseminated intravascular } \\
\text { coagulation, abdominal pain, then septic } \\
\text { shock in an immunocompromised patient } \\
\text { with terminal cancer }\end{array}$ \\
\hline $\begin{array}{l}\text { Female, } \\
20 \mathrm{~s}\end{array}$ & France & Yes & Asthenia, diarrhoea, cough, history of fever \\
\hline $\begin{array}{l}\text { Female, } \\
20 \mathrm{~s}\end{array}$ & Guinea & No & Fever $\left(39 \cdot 5^{\circ} \mathrm{C}\right)$, abdominal pain \\
\hline $\begin{array}{l}\text { Female, } \\
40 \mathrm{~s}\end{array}$ & Guinea & Yes & $\begin{array}{l}\text { History of fever, cough, upper respiratory } \\
\text { tract infection }\end{array}$ \\
\hline
\end{tabular}

At-risk exposure

Final diagnosis

Reported taking care of a relative who died of Ebola infection (this Undetermined information later proved to be untrue)

Non-medical worker in an Ebola treatment centre

Recently hospitalised in Guinea, underwent invasive procedure in a Erysipelas

hospital with Ebola patients and unreliable triage

Reliable assessment of at-risk exposures not possible because of Malaria

patient refusal

Non-reliable assessment of at-risk exposures

ENT infection of

Initial incorrect information about contact with Ebola patients during funerals in a rural setting in Guinea

undetermined origin

Malaise due to the heat

and dehydration

following diarrhoea

Non-reliable assessment of at-risk exposures

Malaria

Non-reliable assessment of at-risk exposures

Malaria due to

Plasmodium falciparum

Non-medical worker who visited Ebola treatment centres (no direct Gastroenteritis of contact with patients)

undetermined origin

Gastroenteritis of

undetermined origin

contact with patients)

Non-medical worker having visited a treatment centre and Ebola

Pneumoniae in an

patients' home without any individual protection (no direct contact with patients)

Deployed for non-Ebola-related research in a healthcare facility managing Ebola patients

At-risk exposures could not be assessed due to the decreased consciousness of the patient

patien

Gastroenteritis of

undetermined origin

Influenza B

HCW who participated in the management of a confirmed case hospitalised in France. No incident/exposure was reported during patient management. The patient was tested as a precautionary measure

Previously hospitalised in Guinea, underwent invasive medical procedures in a hospital caring for Ebola patients treatment centre, no direct contact with patients

Pelvic inflammatory

Campylobacter infection

disease 
Table 2 (cont.)

\begin{tabular}{|c|c|c|c|c|c|}
\hline Sex, age & $\begin{array}{l}\text { Visited } \\
\text { country }\end{array}$ & $\mathrm{HCW}$ & Clinical presentation & At-risk exposure & Final diagnosis \\
\hline Male, $60 \mathrm{~s}$ & Nigeria & No & $\begin{array}{l}\text { History of fever, headache, asthenia, } \\
\text { abdominal pain, loss of appetite, bloody } \\
\text { diarrhoea, conjunctivitis }\end{array}$ & $\begin{array}{l}\text { Non-reliable assessment of at-risk exposures; the patient reported } \\
\text { direct contact with bats }\end{array}$ & $\begin{array}{l}\text { Gastroenteritis of } \\
\text { undetermined origin }\end{array}$ \\
\hline Male, 20s & Guinea & No & Fever $\left(39^{\circ} \mathrm{C}\right)$ & $\begin{array}{l}\text { Previously hospitalised in Guinea in a hospital caring of Ebola } \\
\text { patients }\end{array}$ & $\begin{array}{l}\text { Febrile syndrome } \\
\text { following Yellow fever } \\
\text { vaccination }\end{array}$ \\
\hline Male, $30 \mathrm{~s}$ & Mali & No & History of fever, asthenia & $\begin{array}{l}\text { Hospitalised in Mali in the same ward and at the same time as a } \\
\text { confirmed EVD patient }\end{array}$ & Malaria \\
\hline Male, $30 \mathrm{~s}$ & Guinea & No & History of fever, fatigue, fainting episode & $\begin{array}{l}\text { Participated in non-secured funerals of a relative (cause of death } \\
\text { unknown) in Guinea. The patient carried the body to the grave. } \\
\text { He later seeked medical attention with a traditional healer in } \\
\text { Guinea }\end{array}$ & Anxiety attack \\
\hline Male, $40 \mathrm{~s}$ & $\begin{array}{l}\text { Sierra } \\
\text { Leone }\end{array}$ & No & $\begin{array}{l}\text { Fever } 39 \cdot 6^{\circ} \mathrm{C} \text {, headache, jaundice, } \\
\text { confusion }\end{array}$ & $\begin{array}{l}\text { Non-reliable assessment of at-risk exposures due to the medical } \\
\text { condition of the patient }\end{array}$ & Malaria \\
\hline $\begin{array}{l}\text { Female, } \\
30 \mathrm{~s}\end{array}$ & Guinea & Yes & History of fever, diarrhoea, headache & HCW deployed in an Ebola treatment centre & Undetermined \\
\hline $\begin{array}{l}\text { Female, } \\
30 \mathrm{~s}\end{array}$ & Liberia & Yes & History of fever, cough, sore throat & $\begin{array}{l}\mathrm{HCW} \text { deployed in an Ebola treatment centre for the triage of } \\
\text { patients }\end{array}$ & Bronchitis \\
\hline $\begin{array}{l}\text { Teen-aged } \\
\text { male }\end{array}$ & Guinea & No & $\begin{array}{l}\text { History of fever, headache, upper } \\
\text { respiratory symptoms }\end{array}$ & $\begin{array}{l}\text { Patient reporting that his mother and father had been diagnosed } \\
\text { with Ebola infection in Guinea }\end{array}$ & $\begin{array}{l}\text { Upper respiratory tract } \\
\text { infection of } \\
\text { undetermined origin }\end{array}$ \\
\hline $\begin{array}{l}\text { Teen-aged } \\
\text { male }\end{array}$ & Guinea & No & $\begin{array}{l}\text { Fever }\left(38,8^{\circ} \mathrm{C}\right) \text {, headache, asthenia, } \\
\text { myalgia, diarrhoea, vomiting, fainting } \\
\text { episode }\end{array}$ & $\begin{array}{l}\text { Reported contact with a deceased Ebola patient (post-mortem) and } \\
\text { was hospitalised in a hospital where Ebola patients had been } \\
\text { hospitalised despite the triage }\end{array}$ & Prostatitis \\
\hline Male, 20s & Guinea & Yes & Diarrhoea, history of fever, asthenia & $\begin{array}{l}\mathrm{HCW} \text { deployed in an Ebola treatment centre where he was in } \\
\text { charge of the management of post-mortem procedures including } \\
\text { burials }\end{array}$ & $\begin{array}{l}\text { Gastroenteritis of } \\
\text { undetermined origin }\end{array}$ \\
\hline Male, $50 \mathrm{~s}$ & Guinea & No & $\begin{array}{l}\text { Fever }\left(38 \cdot 8^{\circ} \mathrm{C}\right) \text {, haematuria, asthenia, } \\
\text { enlarged liver and spleen }\end{array}$ & $\begin{array}{l}\text { At-risk exposures could not be assessed due to the medical } \\
\text { condition of the patient }\end{array}$ & Undetermined \\
\hline $\begin{array}{l}\text { Female, } \\
40 \mathrm{~s}\end{array}$ & Guinea & Yes & $\begin{array}{l}\text { Fever }\left(38 \cdot 5^{\circ} \mathrm{C}\right) \text {, headaches, vomiting, } \\
\text { asthenia, rhinitis }\end{array}$ & $\begin{array}{l}\mathrm{HCW} \text { deployed in the treatment centre in Guinea dedicated to } \\
\text { healthcare workers. } \\
\text { Reported an at-risk exposure while working in the triage area }\end{array}$ & Undetermined \\
\hline $\begin{array}{l}\text { Female, } \\
40 \mathrm{~s}\end{array}$ & Guinea & Yes & Fever $\left(38 \cdot 2^{\circ} \mathrm{C}\right)$, fatigue, chills & $\mathrm{HCW}$ deployed in an Ebola treatment centre & $\begin{array}{l}\text { Fever of unknown origin } \\
\text { and short duration }\end{array}$ \\
\hline Male, $50 \mathrm{~s}$ & Guinea & No & History of fever, chest pain. & $\begin{array}{l}\text { Attended funerals in a district with uncontrolled transmission } \\
\text { chains, then hospitalised in the same district, underwent invasive } \\
\text { procedures }\end{array}$ & $\begin{array}{l}\text { Complication of poorly } \\
\text { controlled diabetes }\end{array}$ \\
\hline
\end{tabular}




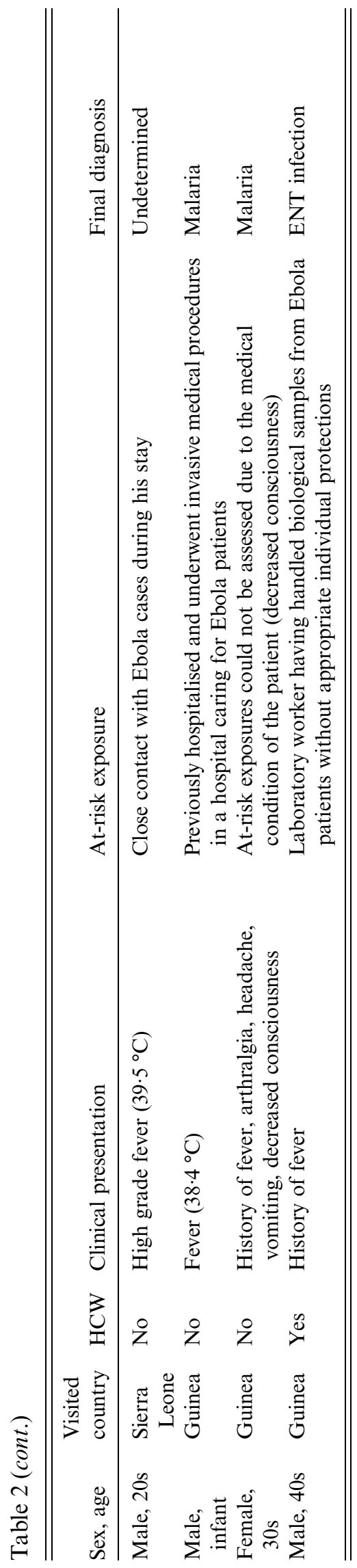

34, sex ratio $\mathrm{M} / \mathrm{F}$ was $1 \cdot 3$ and the median age was 35 years (range 11-95). All but one possible cases were adults ( $>16$ years old).

Twenty-seven $(80 \%)$ travelled from Guinea, two $(6 \%)$ from Sierra Leone, two $(6 \%)$ from Liberia, one $(3 \%)$ from Mali and one $(3 \%)$ from Nigeria. One patient was a HCW who had not travelled from an outbreak area but had provided care to a confirmed case hospitalised in France after being evacuated from West Africa (Table 2). Ten out of 34 were HCW.

All 34 possible cases were excluded after one or two Ebola virus RT-PCR tests, depending on the delay between the onset of symptoms and the first test.

The final diagnosis was known for 29/34 possible cases, of which eight had malaria, seven had respiratory or ear-nose-throat (ENT) infections and five had gastroenteritis of undetermined aetiology.

\section{Confirmed cases}

Two patients with confirmed Ebola infection were hospitalised in France after aeromedical evacuation from West Africa.

Both were HCW deployed, respectively, in Sierra Leone and Guinea. For both patients, the diagnosis had been confirmed by RT-PCR before being safely evacuated to France. They were therefore continuously maintained in isolation since their departure from West Africa until their full recovery and hospital discharge in France. Hospital discharge occurred after clinical recovery and two successive negative RT-PCR in serum and in urine.

No secondary case occurred among HCW workers in charge of the two patients.

\section{Follow-up of contacts}

Five hundred and forty-two asymptomatic persons were evaluated, all on return from the affected area: 238 were military HCW or military workers in charge of security issues; 120 were civilian HCW deployed by non-governmental organisations, 74 were professionals (HCW and non-HCW) deployed in the Ebola treatment centre of Macenta or for the temperature screening in airports, two were journalists, two were epidemiologists and 38 were travellers who reported non-occupational exposures.

Fifty-six $(10 \%)$ were considered to have had highrisk contacts with EVD patients and were actively followed-up. One of them presented with a brief 
episode of fever during the follow-up and was tested for EVD infection with a negative result.

None of the followed-up persons was later diagnosed as a confirmed case.

\section{DISCUSSION}

We report the results of the strengthened surveillance of Ebola infections implemented as a response to the risk of imported cases in France.

The high number of notified patients suggests a good acceptance of the surveillance system. However, the surveillance system probably had a low sensitivity: (1) suspected cases may not have sought medical attention for their symptoms, especially if they were mild; (2) clinicians with a good knowledge about the disease and the outbreak, and who were aware of the criteria for suspected and possible cases may have ruled out the hypothesis of Ebola infection in some patients without notifying the patients. However, we are confident that we did not miss any symptomatic case of EVD, because access to healthcare in France is very good, making it very likely that a patient with severe infection would have been hospitalised. Only cases with mild EVD or asymptomatic infection may have been missed by the surveillance system, and such patients would represent a limited risk of transmission of the virus in the absence of severe diarrhoea or bleeding.

We chose to use fever $\geqslant 38^{\circ} \mathrm{C}$ as a major criterion of the case definition. This choice is questionable as there were reports, during this outbreak and before, of EBOV patients who did not have any fever [14-16]. We nevertheless decided to use this criterion because the probability of an imported case not displaying fever at any time during the disease, especially while shedding the virus, was considered very low. We also considered that the definition of a suspected case would have been much too sensitive without fever. Moreover, some patients with no fever but a serious condition may have been put in isolation although they needed urgent care that may not have been available in the isolation facility (e.g surgical procedures).

The most important criterion in our case definitions was the assessment of at-risk exposures, which were relatively easy to evaluate in most patients. However, the scarce public information about the transmission chains and the absence of information on the reliability on contact-tracing and transmission chains (contact-tracing efficacy, existence of 'sporadic' cases) in the affected countries was challenging: some suspected patients may not have known they had been exposed or may have denied their exposures and we had no way to verify their statement or evaluate their reliability.

In our experience during the strengthened surveillance, and with regard to the possible unreliability of reported at-risk exposures, it was crucial to devote enough time and perseverance to the interview of the suspected cases unless their medical condition was critical. The achievement of a trustful relationship with the patient and the pair clinician/epidemiologist, based on the assurance that the patient would be safely and properly taken care of even in the event of an EBOV infection was a guarantee of a good assessment. Moreover, because some suspected cases were asylum seekers or illegal migrants, it was of major importance to reassure them about the access to healthcare regardless of their legal status.

The exposures of some suspected cases could not be evaluated due to their medical condition, or because they refused to cooperate. For these patients, we chose to be careful, to consider them as possible cases requiring isolation and testing. The set-up of a conference call, involving a multidisciplinary team was much appreciated by all those involved as it lowered the risk to either miss a real case or delay the healthcare access for a patient with another illness.

Eight of 34 possible cases actually had malaria. Such finding is expected due to the lack of specificity of EVD clinical presentation. Not only malaria should be taken into account for the differential diagnosis, but also other infections such as typhoid, dengue, etc. It was therefore recommended in France to give possible cases a presumptive treatment against malaria and severe bacterial infections [17]. Re-enforcing the preventive measures against infectious diseases that are part of the differential diagnosis of EVD in travellers could help limiting the number of suspected and possible cases.

The West African outbreak lasted for more than 2 years and was the longest EBOV outbreak ever described. Moreover, the timeline of the epidemic was complex, with some countries being declared free of transmission chains, then again classified as affected areas due to late sexual transmission from recovered patients. Maintaining the strengthened surveillance on the long term and in this context proved to be difficult both at the national and local levels. The usefulness of the strengthened surveillance and the procedure to safely manage the possible cases were questionable with regards to the low probability 
of an imported case and the cost (human and financial) of the surveillance system. However, the impact of missing an imported case would have been considerable both for public health and the fear of the lay public, and we think it was not acceptable to rely only on the national mandatory notification during this outbreak.

Several models estimated that France was among the top 15 countries with the highest risks of EVD case importation during the outbreak in Western Africa [7, 18]. However, no imported EVD case was identified in France. Temperature screening at departure in affected countries may have contributed to decrease the probability of importing cases in nonaffected countries, as well as the information disseminated to the travellers on departure and during the flights, and the decrease of the number of passengers flying to and from Guinea during the outbreak. These models presented very different estimations for France: from one imported case in 20 months to one in 9 months. Although these figures were low, these estimations contributed to determine the needs in the Ebola outbreak response in France (number of referral hospitals, number of beds in isolation facilities, etc.).

Despite the repeated spread of information about the outbreak to the local health authorities and the clinicians, the sensitivity of the surveillance changed during the outbreak. Indeed, we recorded three peaks of notifications: the first one at the end of summer 2014 was expected and was consistent with an increase in the number of people returning from Guinea before the beginning of school year. The two other peaks occurred after the diagnosis of domestic cases in HCW in Spain and in the USA. These episodes were highly reported by the media and the scientific medical networks and probably raised the medical community and patients' awareness about the possible risk of imported EVD cases in France.

\section{CONCLUSION}

The tragic outbreak that occurred in West Africa from 2014 to 2016 required a preparedness and response system in France. The results of our strengthened surveillance suggest that we did not miss any imported case.

The lessons learnt from this long-lasting strengthened surveillance are the need for continuous training for first-line healthcare professionals to assess the risk of viral haemorrhagic fevers in persons returning from affected areas, and be able to immediately implement control procedures for highly contagious infection. For these purposes, the support from the national level for the epidemiological situation analysis and from the NRC for virological expertise is essential. The multidisciplinary telephone assessment of complex cases proved to be efficient without delaying the management of patients and will be considered for future crisis.

\section{FINANCIAL SUPPORT}

This work was funded by Santé publique France.

\section{CONFLICT OF INTEREST}

None.

\section{REFERENCES}

1. WHO. Ebola haemorrhagic fever in Zaire, 1976. Bulletin World Health Organization 1978; 56: 271-293.

2. WHO. Ebola haemorrhagic fever in Sudan, 1976. Report of a WHO/International Study Team. Bulletin World Health Organization 1978; 56: 247-270.

3. Baize $\mathrm{S}$, et al. Emergence of Zaire Ebola virus disease in Guinea. New England Journal of Medicine 2014; 371: $1418-1425$.

4. WHO. Ebola situation report (http://apps.who.int/ebola/ current-situation/ebola-situation-report-30-march-2016). Accessed 8 September 2017.

5. Direction du traffic aérien. Bulletin statistique annuel du traffic aérien commercial, année 2014. (http://www. developpement-durable.gouv.fr/sites/default/files/ Bulletin_Statistique_2014.pdf). Accessed 27 April 2017.

6. COMEDE (eds). Migrants étrangers en Situation Précaire: Prise en Charge Médico-Psycho-Sociale. Paris: Parimage, 2015, p. 440.

7. Haut Conseil de la Santé Publique. [Expert opinion: anticipating the possible impact in France of the outbreak of Ebola infections in Western Africa]. (http:// www.hcsp.fr/Explore.cgi/Telecharger?NomFichier=hcspa 20141215_ebolaanticipimpactnational.pdf). Accessed 9 February 2017.

8. Ministry of health. Referral hospital habilitated for Ebola patients. (http://social-sante.gouv.fr/IMG/pdf/2015_ 09_10_-_listing_esrh.pdf). Accessed 27 April 2017.

9. Rieger T, et al. Evaluation of RealStar reverse transcription-polymerase chain reaction kits for filovirus detection in the laboratory and field. Journal of Infectious Diseases 2016; 214: S243-S249.

10. ECDC. Rapid risk assessment: Outbreak of Ebola virus disease in West Africa, third update, 1 August 2014. (http://ecdc.europa.eu/en/publications/Publications/ebolaoutbreak-west-africa-1-august-2014.pdf). Accessed 27 April 2017). 
11. Gulland A. Spanish authorities investigate how nurse contracted Ebola. British Medical Journal 2014; 349: g6120.

12. Liddell AM, et al. Characteristics and clinical management of a cluster of 3 patients with Ebola virus disease, including the first domestically acquired cases in the United States. Annals of Internal Medicine 2015; 163: 81-90.

13. Matheron S, et al. Ebola: should we consider influenza vaccination? Lancet 2014; 384: 2023-2024.

14. Qin E, et al. Clinical features of patients with Ebola virus disease in Sierra Leone. Clinical Infectious Diseases 2015; 61: 491-495.

15. Barry M, et al. Ebola outbreak in Conakry, Guinea: epidemiological, clinical, and outcome features. Médecine et Maladies Infectieuses 2014; 44: 491-494.
16. Bah EI, et al. Clinical presentation of patients with Ebola virus disease in Conakry, Guinea. New England Journal of Medicine 2015; 372: 40-47.

17. Haut conseil de la santé publique. AVIS relatif à une demande de précisions sur l'avis du HCSP concernant la conduite à tenir autour des cas suspects de maladie à virus Ebola du 10 avril 2014. 10 Septembre 2014. (http:// www.hcsp.fr/Explore.cgi/Telecharger?NomFichier=hcspa 20140910_conduitecassuspectebolaprecision.pdf). Accessed 27 April 2017.

18. Gomes MFC, et al. Assessing the international spreading risk associated with the 2014 West African Ebola outbreak. PLoS Currents 2014. Edition 1. doi: 10.1371/currents.outbreaks.cd818f63d40e24aef769dda7 df9e0da5. 